\title{
FACTORS AFFECTING CONSUMERS' CONTINUED USE OF INTERNET BANKING: EMPIRICAL EVIDENCE FROM AUSTRALIA
}

\author{
Sujana Adapa \\ University of New England \\ adapa2@une.edu.au \\ Ray Cooksey \\ University of New England \\ rcooksey@une.edu.au
}

\begin{abstract}
The goal of this study was to investigate the factors that influence consumer's continued use of internet banking in Australia. Patterns of continued use of internet banking have been neglected as most of the existing studies focus on either consumer adoption or acceptance of internet banking. However, in comparison to new customer acquisition, measures of continued use of internet banking are important as it is related to a cost-effective marketing strategy aimed at retaining customers. The present study is a response to a gap in existing literature which requires the application of more integrated theory testing and the identification of factors that influence the continued use of internet banking in order of importance to consumers. The study sets out to develop a conceptual framework based on theoretical models related to the acceptance of technology and diffusion of innovations theory. The conceptual model developed encompasses technology, channel, social and value for money factors as predictors in the identification of influential factors for consumers and their continued use of internet banking. Data were collected using a cross-sectional mall intercept survey in the Western Sydney region, comprising a sample of 372 internet banking users. After testing the data for accuracy, exploratory factor analysis was performed for factor clarification on five key scales related to the use of internet banking service delivery based on technology, channel, social, value for money and continued use factors. The final components that emerged were employed in hierarchical multiple regression analyses to test the proposed framework. Value for money, channel and technology factors was found, in that order, to be influential in predicting consumers' continued use of internet banking.
\end{abstract}

Keywords: Continued Use, Internet Banking, Value for money Factors, Channel Factors, Technology Factors

\section{INTRODUCTION}

The traditional modes of conducting many businesses has been changed over a period of time due to the advent of the internet, rapid technological evolutions, globalisation, financial deregulations, liberalisation and consolidation of the financial markets (Mia et al. 2007). Several modern businesses 
are also utilising technological advancements in order to make their services more accessible to consumers (Reid \& Levy 2008). The retail banking sector is one such business entity that has been using a wider array of information systems to satisfy its customers (Wresch \& Fraser 2006). The retail banking industry has also realised that relying exclusively on the traditional price-related factors for competition was a questionable way to increase revenue and market share in the industry (Durkin et al. 2008). The two largest expenses incurred by banks are associated with the maintenance and overhead costs of branch networks and their associated human resources (Durkin 2004). Banks started to realise that relying on non-price factors provided alternative strategies for differentiation, gaining competitive advantage and cost cutting (Daniel 1999). As a result, the financial services industry has become much more competitive over the last few years (Thornton \& White 2001).

In an intensifying competitive environment, superior distribution strategies relating to how to communicate with, and deliver products to, the customer effectively provides a comprehensive advantage to the banking institutions (Kerem et al. 2003). Moreover, customers are also demanding greater convenience and accessibility, as reflected in longer branch opening hours and an increase in the choice of service delivery mechanisms. On a global scale, many banks have started to set in place more cost-effective alternative service delivery systems (Shih \& Fang 2004). The trend has seen the proliferation of multiple service delivery channels through which consumers can interact with banks. Therefore, modern banks provide their consumers with increased channel choice that reaches out to consumers through many different routes. Alternative service delivery systems such as Automated Teller Machines (ATMs), telephone, internet and wireless channels are now available to the consumers to perform their banking transactions in addition to the traditional branch banking (Reid \& Levy 2008; Akinci et al. 2004).

The growing use of technologies in services has revolutionised the interactions between service providers and customers and increased standardisation of many services (Liljander et al. 2006). The introduction of new service delivery channels increases the productivity and efficiency of the service providers apart from offering access to customers, thereby better meeting customer demand and increasing satisfaction (Liljander et al. 2006; Walker et al. 2002). Internet banking facilitating electronic transactions is a key facilitator of communication in business activities and in consumer's day-to-day activities (McCole \& Ramsay 2009). The decision to perform internet banking is at the consumers' discretion, indicating the importance of the consumer in electronic interactions. It is critical for business success to understand how consumers make decisions to use internet banking and at the same time, how marketers try to understand consumers' values, beliefs and preferences (Lindgreen \& Wynstra 2005).

Existing customers represent a valuable asset to the service provider. From the bank's perspective, maintaining and retaining their existing customer base is always more profitable than trying to acquire new customers (Srinivasan et al. 2002). Therefore, banks continuously scan and attempt to persuade customers not to switch to competitors in order to maximise their sales and profits (Hammond \& Ehrenberg 1995). Customer participation has always been an indispensable part of any service delivery process (Karmarkar \& Pitbladdo 1997). The management of the service delivery channel performance presents an unusual problem in that the performance of the service system is affected by the actions of customers who may feel uncertain about their capabilities and goals.

In the past decade, the objective of most research in internet banking research has been to analyse the acceptance and adoption of internet banking service delivery channels and to understand the factors, which lead to the adoption process (Chen et al. 2005). There are multitudes of internet banking 
studies that have investigated factors that influence a consumer's intention to adopt or their acceptance of internet banking (Gerrard \& Cunningham 2003; Lee et al. 2003). A persistent argument is that prior studies on internet banking adoption by consumers, and the factors responsible for their adoption of the internet, have produced inconclusive and sometimes conflicting results. This has culminated in a difficulty in articulating the precise findings of internet banking research (Ndubisi \& Sinti 2006). Thus, the findings from research on internet banking from the consumer's perspective remains unclear and in many ways impractical as it is not applied to the business context.

Since its introduction, internet banking, due to its speed and convenience, has been widely accepted by consumers as a service innovation (Klopping \& McKinney 2004). In recent years, Internet Banking transactions increased to a greater extent, indicating the voluminous nature of transactions carried out by the internet banking consumers (Kasheir et al. 2009). This phenomenal uptake and use of internet banking, together with the internet banking experience, modifies the behaviour of individuals towards the channel (Gefen et al. 2003). Change is evident in consumer's initial perceptions and heightens the need to understand not only consumer's pre-adoption behaviour, but also post-adoption behaviour (Yu et al. 2005).

It is only recently that researchers have started to understand the importance of consumers' continued use of internet banking and its impact on the financial performance of the banking sector (Kasheir et al. 2009; Yousafzai et al. 2005). Continued use of internet banking by customers is often neglected in the marketing literature, as most studies focus on either consumer adoption or acceptance of internet banking (Eriksson \& Nilsson 2007). However, in practice, in comparison to new buyer acquisition, continued use is related to a cost-effective marketing strategy aimed at retaining customers. The goal of any business entity in the long term is to increase its productivity and maximisation of the profits. Retention strategies foster customer relationship management and reduce customer switching behaviour (Kasheir et al. 2009). In order to achieve this, it is vital to concentrate on the consumers' continued use of a particular product or service rather than solely on their acceptance of the service (Kim \& Malhotra 2005). With these considerations in mind, and the existing gaps in the knowledge surrounding consumers' continued use of internet banking, the present study focuses on exploring the antecedents to consumers' continued use of internet banking.

\section{LITERATURE SYNTHESIS}

Methodologically speaking, it has become increasingly important for researchers to focus on integrating relevant theories and developing hybrid models for the development of theory in the academic context (Kasheir et al. 2009; Yousafzai et al. 2005). The present study uses theoretical models of technology acceptance and diffusion of innovations theory and integrates them in order to identify the potential factors that might have an impact on consumers' continued usage of internet banking. The value of integrating models lies in the ability of the findings from such research to be more robust and less open to criticisms based on reliability and validity of the findings.

Nevertheless, in recent years, internet banking has shown increasing uptake by consumers and there are more and more consumers who have carried out internet banking transactions several times. This, together with the fact that when consumers have experience with internet banking their behaviour is modified, which produces a change in their initial perceptions about internet banking. Such a change in consumer behaviour makes it necessary to study not only the pre-adoption behaviour of consumers, as in previous research, but also the post-adoption behaviour towards internet banking (Hernandez et 
al. 2008). Therefore, the objective of the present study is to analyse the post-adoption behaviour of experienced internet banking users in identifying what factors influence consumers to continue to use internet banking. Thus, from the existing research, possible theoretical models that provide a comprehensive understanding of user acceptance of innovations come from disciplines such as information systems, psychology and sociology.

According to Bagozzi (2007) the Theory of Reasoned Action (TRA), Theory of Planned Behaviour (TPB) and Technology Acceptance Model (TAM) models all seem to neglect group, social and cultural aspects of the consumer decision-making process. Mostly these models depend on a purely deterministic framework and often self-regulation processes are not taken into consideration. The models also attempt to evaluate the consumers' post-purchase decision-making process; however, in reality, these theories rely on consumers' perceptions of innovation characteristics as a significant predictor of behavioural intention. However, Kasheir et al. (2009) and many researchers believe that these theories are incomplete and that integrating aspects of these theories provides a better understanding and explanation of consumer evaluation of the post-purchase decision-making process rather than what is provided by each theory alone.

Consumers' continued use of internet banking assessment may be more complex than current theories explain, due to the fact that consumers often need to abandon or minimise their current behaviour and usual concerns associated with technological advancements (Falk et al. 2005). Also, usage depends upon an individual's capability and capacity to engage with these proliferated service delivery channels (Walker \& Johnson 2006). Often, continued use is related to the technology updating mechanisms (Kim \& Malhotra 2005). Consequently, existing models, whilst indicative of internet usage behaviour, are not complete in terms of all of the factors consumers refer to in their decisionmaking.

Technological advances in society have an impact on marketing practices. Information and knowledge about markets, customers and competitors becomes more complex and available with the implementation of technological innovations (Rust \& Espinoza 2006). As a result, better services can potentially be offered by companies to satisfy each customer's specific needs. Thus, a clear shift from traditional product orientation to customer orientation in marketing practice is evident as businesses vigorously compete in the application of technology to services (Lovelock \& Wirtz 2004). Therefore, service delivery has become the central focus of many businesses today, paving the way for a new paradigm described as 'the service revolution'. Existing research has revealed the multifaceted use of technology-enabled products and services (Ye et al. 2008). The influence exerted by technological innovations in pre-adoption consumer behaviour has been acknowledged by researchers (Jha et al. 2006). The simultaneous interactions of consumers with technology have caused them to experience positive and negative reactions about the use of technology (Parasuraman 1997). An array of consumer reactions such as control, competence, efficiency and assimilation can be triggered when consumers experience technological interactions (Mick \& Fournier 1998, p.126). In order to cope with technologies, consumers engage in different strategies that range from non-adoption and ignorance, to actual adoption and usage (Parasuraman 2000). However, consumers continue to modify and innovate with technology artefacts, even after adoption of a technology-associated product or service (Desouza et al. 2007). The role played by technology-related factors during consumers' postadoption behaviour remains unexplored. As consumer's level of experience and sophistication in using a particular technology becomes elevated, consumers' expectation of the service suitability to their specific needs also increases (Ye et al. 2008). 
The past decade has seen some of the most rapid and substantive changes in channels of distribution for goods and services in many economies (Black et al. 2002). The advent of the internet challenged the traditional role played by many intermediaries and presented buyers with a choice in terms of their distribution channel usage. Today's consumers are exposed to several service delivery channels and researchers in this area tend to concentrate on understanding and analysing channel design strategies, instead of the issue of channel selection and usage which have received relatively little attention in the existing literature (Yousafzai et al. 2005). Such trends therefore highlight the growing need to understand the ways in which consumers may choose between alternate channels and the circumstances under which one channel may be chosen over another (Black et al. 2002). The proliferation of service delivery channels is evident in the financial services context, specifically in the retail banking sector. Much of the initial channel adoption literature in financial services marketing research focused attention on ATMs (Rugimbana 1995). In the 1990s, there was a shift in interest towards telephone banking (Lockett \& Littler 1997) and electronic banking (Liao et al. 1999). Subsequent studies focused specifically on internet banking (Black et al. 2001), although the initial focus of attention was on the activities undertaken in organisations rather than on the behaviour of consumers (Black et al. 2002). Some later studies started realising the importance of consumers and their channel interactions and emphasised the degree of congruence between a particular service and a channel (Morrison \& Roberts 1998). Moreover, existing research also concentrated on identifying factors influencing a consumer's decision to adopt a particular channel as well as multiple channels (Bell \& Lyman 1999).

The approach of the present study is different in two ways. Firstly, it makes an attempt to focus on consumer channel interactions during their post-adoption behaviour. Secondly, channel-related factors are identified as consisting of components such as consumers' perceptions of their self-efficacy, risk, trust and personalisation. Finally, the study attempts to examine the influence of these channel factors on consumers' continued use of internet banking.

Social influence is identified extensively in the existing literature as normative pressure, while subjective norm refers to a person's perception of the social pressures put on him/her to perform or not to perform the behaviour in question (Ajzen \& Fishbein 1980). Thus, social influence has been treated in the existing literature as analogous to the subjective norm construct incorporated in the TRA and the TPB (Moore \& Benbasat 1991). The role of social influence in an individual's decision whether or not to use a technology is complex and subject to a wide range of contingent influences (Venkatesh et al. 2003). Internet banking as a service innovation creates uncertainty and individuals who are uncomfortable with uncertainty will tend to interact with their social network before making a decision (Lu et al. 2005). Mathieson (1991) reported that social variables could be important in influencing consumers' perceptions if they capture variance that is not already explained by other variables. Taylor \& Todd (1995) decomposed the sources of social influence into peers, superiors and subordinates. The influence from peers and superiors significantly relate to the subjective norm construct that leads to consumers' behavioural intention and usage of technology. The role of social norms in information technology usage literature to date is somewhat unclear (Yousafzai et al. 2003). The study of the influence exerted by the social factors construct on consumers' adoption of internet banking and internet-based technologies produced mixed and inconclusive results (Ma \& Liu 2004).

The creation of value is key in marketing (Lindgreen \& Wynstra 2005). The role of marketing is 'to assist the firm to create value for its customers that is superior to competition' (Tzokas \& Saren 1999, p.53). It is essential to know what consumers actually value before one can truly understand the 
choice of a particular service delivery channel, and its continued usage. It is also of equal interest in identifying the attributes that are most important in consumers' judgments of value. The present study focuses on the value that is derived from the disposition of products and services and extends it to the service delivery channels choice generally, and specifically to the internet banking context. The diversity associated with the meanings of the value concept indicated the difficulty of conceptualisation of the value construct. In this study, value factors relate to consumers' perceptions and expectations of value. The concept of perceived value stems from equity theory. Perceived value is identified as the ratio of the consumers' outcome/input to that of the service providers' outcome/input (Oliver \& DeSarbo 1988). In other words, the equity concept refers to customer's evaluation of what is fair, right or deserved for the perceived cost of the offering (Bolton \& Lemon 1999). The choice of a particular banking service delivery channel, its subsequent acceptance, and continued usage depends on consumers' expectations of the value offered. It is important to understand what consumers' value for and what the important dimensions are, that play a critical role in their judgments of value offering. Perceived value represents a consumers' overall assessment of the utility based on perceptions of what is received and what is given (Zeithaml 1988). Also, perceived value is identified in the literature as a trade-off between the perceived benefits and perceived costs derived by the consumers from using a particular channel. Monetary payments and non-monetary sacrifices, such as time consumption and stress experienced by consumers, together include perceived costs (Yang \& Peterson 2004), whereas, customer perceived value emerges from an evaluation of the relative rewards and sacrifices associated with the offering.

The conceptual framework shown in Figure $I$ has a predictive intent. The demographic characteristics include gender, age, level of education, level of income, ethnicity and occupation. The specific order of entry of the predictor variables was based on the theoretical and logical considerations. Demographic characteristics are not of research interest as their influence has been widely acknowledged in the existing research. Therefore, demographic characteristics will be statistically controlled for in order to avoid any confounding effects they might exert on the predictor variables. This will be accomplished by entering the demographic set of variables first in the hierarchical predictive model. Technology factors related to the context of internet banking will be entered into the model at the second step and are expected to significantly predict consumers' continued usage of internet banking over and above the variability explained by the demographic set. Technology-related factors were considered to be important, as consumers, during their post-adoption, tend to be more confident with the use of the technology-enabled internet banking service delivery channel. In the third step, channel factors will be entered to significantly predict consumers' continued usage of internet banking over and above the influence exerted by the demographic characteristics set and technology factors. The order of entry of channel-related factors was based on the theoretical foundations and the role attributed to the consumers' psychographics in the existing literature (Black et al. 2002). In the fourth step, social factors will be entered in to the model and will be expected to significantly predict variability in the criterion variables over and above the previously entered demographics set, technology and channel factors. The order of entry of the social factors was of theoretical importance, asserted to the influence of the peers, friends and family members in influencing consumers' behaviour, once the consumer encompasses contextual and psychological factors. Finally, value for money factors will be entered into the model expected to significantly predict the criterion variables over and above those of previously entered predictor variables. 


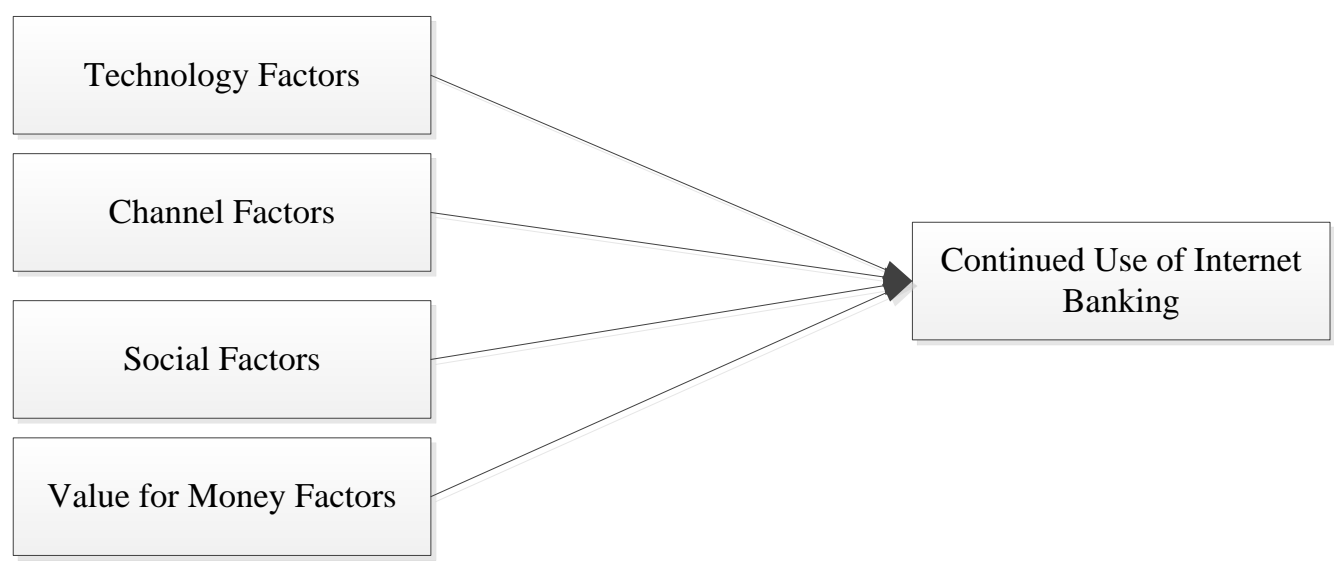

Figure 1: Overall conceptual framework showing the order in which variables sets will be considered in the prediction of Continued Use of Internet Banking

\begin{tabular}{|l|l|}
\hline $\mathbf{H}_{1}:$ & $\begin{array}{l}\text { Identified technology factors will significantly predict continued usage of internet banking } \\
\text { over and above the influence of the demographic control variables. }\end{array}$ \\
\hline $\mathbf{H}_{\mathbf{2}}:$ & $\begin{array}{l}\text { Identified channel factors will significantly predict continued usage of internet banking over } \\
\text { and above the influence of the demographic control variables and technology factors. }\end{array}$ \\
\hline $\mathbf{H}_{\mathbf{3}}:$ & $\begin{array}{l}\text { Identified social factors will significantly predict continued usage of internet banking over } \\
\text { and above the influence of the demographic control variables, technology and channel } \\
\text { factors. }\end{array}$ \\
\hline $\mathbf{H}_{\mathbf{4}}:$ & $\begin{array}{l}\text { Identified value for money factors will significantly predict continued usage of internet } \\
\text { banking over and above the influence of the demographic control variables, technology, } \\
\text { channel and social factors. }\end{array}$ \\
\hline
\end{tabular}

\section{RESEARCH METHODOLOGY}

The present study was conducted in the Sydney region, as it is a financial centre in Australia, as well as the location where a majority of the retail banks conduct their operations. The questionnaire was distributed to both the users and non-users of internet banking. Out of the 1308 respondents intercepted in the foyer of the shopping mall, 698 respondents answered the survey questionnaire on the spot. Of these questionnaires obtained, only 683 questionnaires were valid with complete responses, thus indicating 52.5 percent of the response rate. Among the 683 usable questionnaires, 372 were completed by users and the remaining 311 by non-users of internet banking. For the purpose of this study, only questionnaires obtained from the internet banking users $(n=372)$ has been taken into consideration for subsequent analysis.

The survey instrument consisted of questions pertaining to respondent's general banking habits and internet usage, demographic characteristics, scale items and open-ended questions, organised into logical sections. Questions related to general banking behaviour, internet usage and demographic characteristics were incorporated in the questionnaire irrespective of the respondent's internet banking 
usage pattern. To begin with, the questionnaire consisted of an open-ended question asking the nonusers of internet banking to give the reasons why they do not use internet banking. If respondents did not use internet banking they were thanked for their participation and then screened out of the survey. The questionnaire then goes on to obtain answers from internet banking users, which contained items on technology, channel, social, value for money and continued use factors. All the five scales representing the major variables were used by researchers in different contexts whose validity and reliability had been established in previous studies. Furthermore, the survey also had an open-ended qualitative section included at the end in order to collect the respondent's opinions about their internet banking patterns from the users of internet banking.

Technology factors included in the present study were operationalised in a manner consistent with previous internet banking studies in other research contexts (Hernandez \& Mazzon 2007; Chan \& Lu 2004; Tan \& Teo 2000; Moore \& Benbasat 1991). For this study, technology factors were measured using a 17 item scale consisting of five sub-dimensions such as relative advantage, compatibility, complexity, trialability and result demonstrability (Moore \& Benbasat 1991). Channel factors were operationalised in accordance with work by Hernandez \& Mazzon (2007), Chan \& Lu (2004), Tan \& Teo (2000), Rhee \& Riggins (1997), and Lee (1996). Channel factors were measured using the 15 item scale consisting of four sub-dimensions such as perceived self-efficacy, perceived risk, perceived trust and perceived personalisation (Hernandez \& Mazzon 2007; Tan \& Teo 2000).

Social factors were operationalised consistent with work by Chan \& Lu (2004), Venkatesh \& Davis (2000), and Tan \& Teo (2000). In this study, social factors were measured using the six-item scale consisting of two sub-dimensions subjective norm and interpersonal influence. Value for money factors were operationalised in accordance with work by Thomas \& Sullivan (2005), Keen et al. (2004), Petrick (2002), Zeithaml et al. (2002), and Sweeney \& Soutar (2001). In this study, value for money factors was measured using the eight-item scale consisting of two sub-dimensions perceived benefits and perceived costs.

Continued use factors were operationalised consistent with work by Hernandez \& Mazzon (2007), Chan \& Lu (2004), and Venkatesh \& Davis (2000). Continued use factors were measured using a three item scale without any sub-dimensions. Data were collected from the respondents who were current internet banking users, using the aforementioned scale items, which used a six-point Likert scale defined as (1) Strongly Agree, (2) Agree, (3) Neither Agree nor Disagree, (4) Disagree, (5) Strongly Disagree, and (6) Unable to Rate.

Initially all questionnaires obtained were checked for completeness. Vetting of the questionnaires obtained was done with the objective of increasing accuracy and precision. Vetting was done by screening the questionnaires to identify illegible, incomplete, inconsistent and ambiguous responses. A coding process was followed involving the assignment of a code to represent a specific response to a specific question along with the data record and column position that code will occupy. Whilst performing data coding it was ensured that all the data were numeric, each variable for each respondent occupied the same column in the SPSS data editor, all the codes assigned for a variable were mutually exclusive, each variable was coded in order to obtain maximum information and coding rules were applied consistently for all respondents (Cohen et al. 2003). Coded data were entered from the questionnaires to SPSS 17.0 computer program (SPSS 2008). The SPSS data records were checked thoroughly and extensively for consistency and missing responses as part of the data cleaning process. 


\section{RESULTS}

The demographic profile of the participants who responded to the survey as internet banking users and non-users of internet banking indicated that there were more males $(53.8 \%)$ in the sample of internet banking users than females. Among the non-users of internet banking there were more females $(65.9 \%)$ than males. Maximum numbers of the respondents identified were within the age range of 31 to 40 years as internet banking users and non-users represented as $28.2 \%$ and $22.5 \%$ respectively. The majority of the internet banking users had attained a higher education level, whilst for the majority of non-users of internet banking the highest level of education was at the vocational education and training level $(45.7 \%)$. Internet banking users $(21.2 \%)$ were within the income range of $\$ 80001$ and over, and non-users of internet banking $(28.6 \%)$ were within the income range of $\$ 50$ 001- $\$ 65$ 000. Most internet banking users were of Asian ethnicity (23.7\%) and most non-users were Anglo-Australians $(22.8 \%)$ in the sample. Maximum numbers of the respondents as internet banking users were derived from the managerial occupation (30.1\%). The maximum number of respondents as internet banking non-users was reported from the managerial (18.6\%) and administration (18.3\%) categories.

Exploratory factor analysis was performed using principal components and promax rotation. Certain scale items were deleted from entering further analysis as they did not meet the essential criteria such as low factor loading values, less eigenvalues or low item-to-total correlations (Hair et al. 2006). The log transformed scale items 'Internet banking can be frustrating (LTD5)', 'Internet banking is an easy way to conduct banking transactions (LTD11)', and 'I would have difficulty explaining to others why using internet banking may be beneficial (LTD17)' of technology factors were deleted from the original scale due to the presence of factor loadings with an absolute value of less than 0.4. Similarly, the scale item 'Performing internet banking transactions makes me feel psychologically uncomfortable (LCD8)' was deleted from the channel factors due to the presence of low loading values. A refined exploratory factor analysis was performed excluding the scale items that did not satisfy the assumptions of the exploratory factor analysis.

\section{Principal Component Analysis Output for the Technology Factors}

The principal component analysis method and a promax rotation of the technology determinants constituting fourteen scale items was conducted on a random sample $(\mathrm{N}=372)$ of Australian internet banking users and is presented in Table I. A two-component solution provided the clearest extraction, using the Kaiser-Guttman retention criterion of eigenvalues of more than one. The component correlation matrix indicates that the two components emerged from the technology factors to be positively correlated (0.42) at a moderate level, are fairly well discriminated and accounted for 38.23 percent of the total variance. Table I presents the fourteen scale items, communality estimates and eigenvalues.

The two technology factors components were labelled based on a review of the thematic content of the different items of their defining items. 'Perceived Usability' component consists of items relating to the consumer's extent of ease and convenience with internet banking, compatibility with their personal and professional lifestyles and the extent to which they could communicate the benefits of internet banking usage to others. 'Perceived Trialability' component relates to the extent to which customers can actually try internet banking or any add on features with regard to internet banking on a limited basis before they actually consume the service. 


\begin{tabular}{|l|l|l|}
\hline \multirow{2}{*}{ Scale items } & \multicolumn{2}{l|}{ Factors } \\
\cline { 2 - 3 } & 1 & 2 \\
\hline LTD3 Internet banking allows me to manage my finances more efficiently & 0.71 & \\
\hline LTD2 Internet banking gives me greater control over my finances & 0.70 & \\
\hline LTD6 Internet banking is compatible with my lifestyle & 0.70 & \\
\hline LTD7 Using internet banking fits well with the way I like to manage my finances & 0.68 & \\
\hline LTD4 Internet banking is a convenient way to manage my finances & 0.67 & \\
\hline LTD8 Using the internet to conduct banking transactions fits into my working style & 0.65 & \\
\hline LTD10 Internet banking is useful for managing my financial resources & 0.53 & \\
\hline LTD1 Internet banking makes it easier for me to conduct my banking transactions & 0.51 & \\
\hline $\begin{array}{l}\text { LTD16 I believe I could communicate to others the consequences of using internet } \\
\text { banking }\end{array}$ & 0.46 & \\
\hline $\begin{array}{l}\text { LTD17 I would have no difficulty explaining to others why using internet banking } \\
\text { may be beneficial }\end{array}$ & 0.41 & \\
\hline LTD9 Internet banking does not require a lot of mental effort & 0.45 & \\
\hline $\begin{array}{l}\text { LTD12 Prior to the actual adoption, internet banking is available for me to use on a } \\
\text { trial basis }\end{array}$ & & 0.84 \\
\hline $\begin{array}{l}\text { LTD14 I have a great deal of opportunity to try internet banking before the actual } \\
\text { adoption }\end{array}$ & & 0.79 \\
\hline $\begin{array}{l}\text { LTD13 I am able to use internet banking to see what it can do for me prior to the } \\
\text { actual adopti0on }\end{array}$ & & 0.76 \\
\hline $\begin{array}{l}\text { Eigenvalues } \\
\text { KMO } \\
\text { Bartlett's test of sphericity }\end{array}$ & 3.93 & 2.06 \\
\hline Factor Correlation Matrix & 0.81 & F $<$ \\
\hline & 0.001 & \\
\hline Factor 1 & 0.42 & \\
\hline Factor 2 & 1.00 & \\
\hline
\end{tabular}

Table 1: Summary of Principal Component Analysis for Technology Factors Measure (N = 372)

\section{Principal Component Analysis Output for the Channel Factors}

The results of the principal component analysis output for the channel factors are presented in Table II. Using the Kaiser-Guttman retention criterion of eigenvalues greater than one, a two-component solution provided the clearest extraction. These two components accounted for 36.59 percent of the total variance. The two component model was deemed to be the best solution because of its conceptual clarity and ease of interpretation. Also, the component correlation matrix reveals that the two emerged components of the channel-related factors to be moderately positively correlated $(0.34)$ and are well discriminated. 


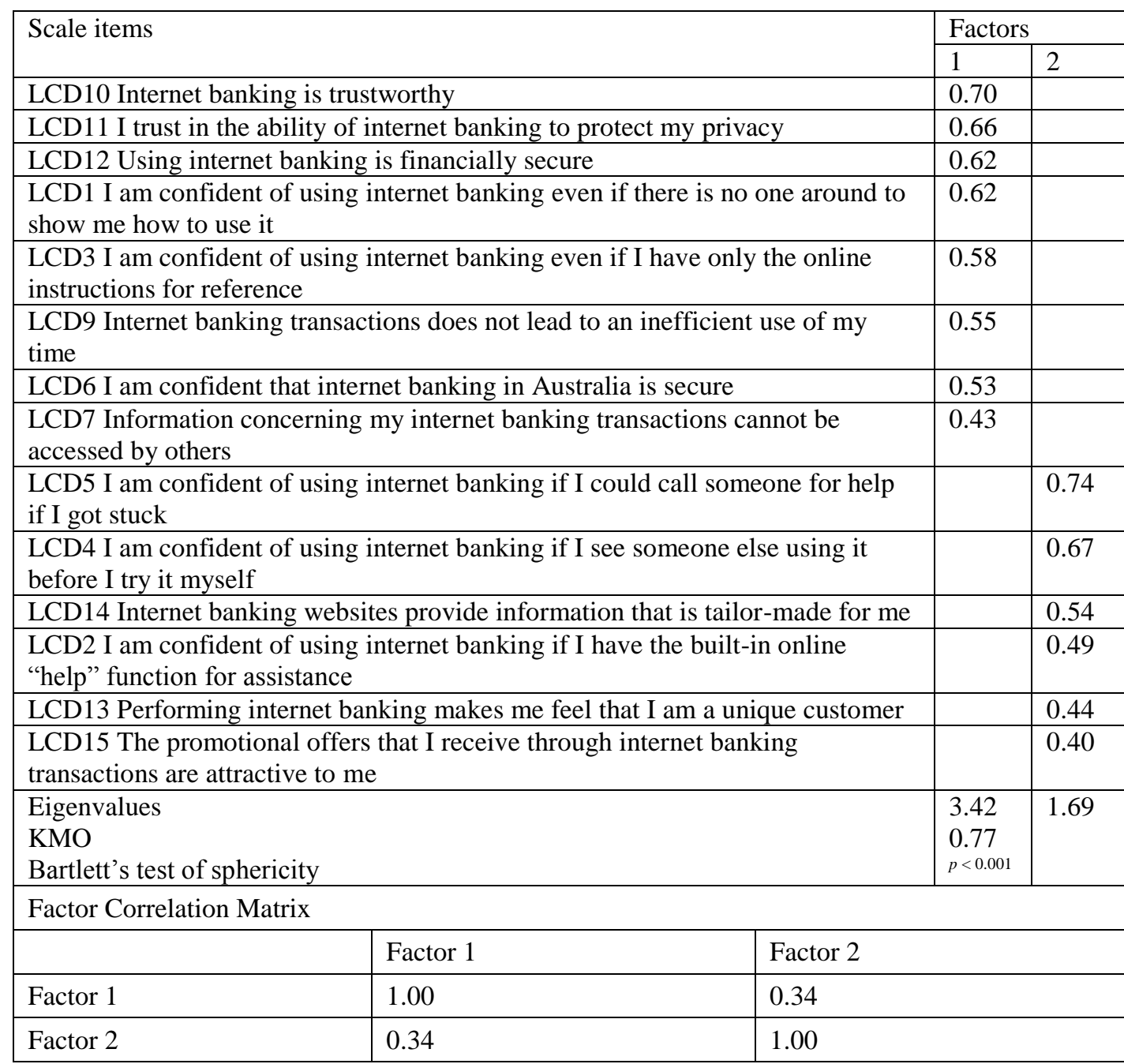

Table 2: Summary of Principal Component Analysis for Channel Factors Measure $(\mathrm{N}=372)$

The two channel factors components were labelled based on a review of the thematic content of the different items of their defining items. 'Perceived Safety' component relates to the safety of internet banking with regard to the risk, security and trust associated by the consumers with internet banking as a service delivery channel. Moreover, the component included items related to the internal component of self-efficacy, indicating that internet banking users were confident that they can perform their transactions without any help. 'Perceived Specialty' component is related to the personalisation component perceived by the consumers as unique and special customers due to their act of performing internet banking. Perceived specialty component also consists of the external component of self-efficacy, indicating less confidence associated with the internet banking consumers without the presence of a role model or online help functions. 


\section{Principal Component Analysis Output for the Social Factors}

The results obtained from the principal component analysis for the social factors are presented in Table 3. The Kaiser-Guttman retention criterion of eigenvalues greater than one provided the clearest extraction of a one-component solution. The resultant single component accounted for 64.72 percent of the total variance.

\begin{tabular}{|l|l|}
\hline Scale items & Factor \\
\hline LSD1 My decision to use internet banking is influenced by my friends & 0.72 \\
\hline LSD2 My decision to use internet banking is influenced by my family & 0.63 \\
\hline LSD3 My decision to perform internet banking is influenced by my colleagues & 0.70 \\
\hline $\begin{array}{l}\text { LSD4 I frequently gather information from friends about internet banking before I } \\
\text { actually perform any transactions }\end{array}$ & 0.73 \\
\hline LSD5 I often check with others to make sure that I am properly using internet banking & 0.67 \\
\hline $\begin{array}{l}\text { LSD6 I often observe how others conduct their banking transactions before I actually } \\
\text { perform any transactions }\end{array}$ & 0.41 \\
\hline $\begin{array}{l}\text { Eigenvalues } \\
\text { KMO } \\
\text { Bartlett's test of sphericity }\end{array}$ & 3.88 \\
\hline
\end{tabular}

Table 3: Summary of Principal Component Analysis for Social Factors Measure $(\mathrm{N}=372)$

Principal component analysis for the social factors construct resulted in an extraction of a single solid component consisting of the scale items related to the influence exerted on the customer to use internet banking by the friends, family members and colleagues.

\section{Principal Component Analysis Output for the Value for money Factors}

Table 4 shows the principal component analysis solution for the value for money factors construct. The Kaiser-Guttman retention criterion of eigenvalues greater than one provided the clearest extraction of one solid component solution. The resultant component accounted for 38.19 percent of the total variance.

\begin{tabular}{|l|l|}
\hline Scale items & Factor \\
\hline LCPV1 Internet banking is very reliable & 0.46 \\
\hline LCPV2 Internet banking is of outstanding quality & 0.43 \\
\hline LCPV3 Internet banking provides easy access to information & 0.48 \\
\hline LCPV4 I am happy with the price charges for performing internet banking & 0.42 \\
\hline LCPV5 Internet banking has a good reputation in Australia & 0.58 \\
\hline LCPV6 Internet banking transactions can be performed with very little effort & 0.59 \\
\hline LCPV7 Performing internet banking transactions is the right decision when price & 0.47 \\
and other expenses are considered & \\
\hline LCPV8 Internet banking transactions are economical & 0.69 \\
\hline Eigenvalues & 3.05 \\
KMO & 0.82 \\
Bartlett's test of sphericity & $\mathrm{p}<0.001$ \\
\hline
\end{tabular}

Table 4: Summary of Principal Component Analysis for Value for money Factors Measure $(\mathrm{N}=372)$ 
The principal component analysis solution for the value for money factors resulted in the extraction of a single component consisting of the scale items representing the trade-off between the benefits and costs associated by the customer with the use of internet banking as a service delivery channel.

\section{Principal Component Analysis Output for the Continued Use Factors}

Table 5 displays the summary of principal component analysis for continued use factors measure. The Kaiser-Guttman retention criterion of eigenvalues greater than one provided the clearest extraction of a single solid component solution. The resultant component accounted for 57.39 percent of the total variance.

\begin{tabular}{|c|c|}
\hline Scale items & Factor \\
\hline LUD1 Internet banking usage is a positive experience for me & 0.61 \\
\hline $\begin{array}{l}\text { LUD2 I intend to use internet banking regularly to perform my banking } \\
\text { transactions }\end{array}$ & 0.66 \\
\hline LUD3 I intend to increase my use of internet banking transactions in future & 0.45 \\
\hline $\begin{array}{l}\text { Eigenvalues } \\
\text { KMO } \\
\text { Bartlett's test of sphericity }\end{array}$ & $\begin{array}{l}1.72 \\
0.61 \\
p<0.001\end{array}$ \\
\hline
\end{tabular}

Table 5: Summary of Principal Component Analysis for Continued Usage Factors Measure $(\mathrm{N}=372)$

Principal component analysis of the continued usage factor extracted a single component. The resultant component consists of scale items related to the customer's associations with internet banking, intention to perform banking transactions through the internet regularly, and their intentions to increase the use of internet banking in future.

\section{Reliability Analysis}

Cronbach's alpha is the most common form of internal consistency reliability coefficient. By convention, a lenient cut-off of 0.60 is common in exploratory research; alpha should be at least 0.70 or higher to retain an item in an 'adequate scale', and a cut-off of 0.80 is required for a 'good scale' (Graham 2006). In the present study, an approach guided by a lenient cut-off of 0.60 is considered to be appropriate. The reliability statistics for the scales identified via principal components analysis are presented in Table 6. In all cases, Cronbach's alpha exceeded at least 0.60. For all subsequent analyses, respondents were given scores on each identified component or scale by averaging the scores on the items that defined that scale.

\begin{tabular}{|l|l|l|l|}
\hline Variable & Sub-scale & $\begin{array}{l}\text { Number of } \\
\text { items }\end{array}$ & $\begin{array}{l}\text { Cronbach's } \\
\text { alpha }\end{array}$ \\
\hline Technology factors & Perceived usability & 11 & 0.81 \\
\cline { 2 - 4 } & Perceived trialability & 3 & 0.75 \\
\hline \multirow{2}{*}{ Channel factors } & Perceived safety & 8 & 0.73 \\
\cline { 2 - 4 } & Perceived specialty & 6 & 0.60 \\
\hline Social factors & & 6 & 0.89 \\
\hline Value for money factors & & 8 & 0.76 \\
\hline Usage factors & & 3 & 0.62 \\
\hline
\end{tabular}

Table 6: Reliability Statistics 
The main aim of the study was to predict the power of the continued use of internet banking to influence a specific order of independent variable sets, thus assessing the unique contribution of each set of independent variables. Such a task is ideally suited to the statistical analysis of hierarchical multiple regression (Cooksey 2007). The specific order of entry of the independent variable sets was based both on logical and theoretical considerations (Kasheir et al. 2009; Black et al. 2002, 2001), resulting in a parsimonious model. Demographic variables were entered at the beginning of the analyses based on the logical consideration to control for their influence. The order of entering the technology, channel, social and value for money factors was based on the theory as discussed in the literature synthesis. Hierarchical multiple regression analyses was important as 'semi-partialling' or 'the statistical removal of the influence of one or more variables from the correlational relationship between two variables' (Cooksey 1997, p. 78-79). Thus, the partialling set of variables to be controlled for are considered first, followed by the actual predictor variables of interest which are added subsequently.

Table 7 summarises the different independent variable sets and their constituent predictor variables in the order in which the sets would be entered into the hierarchical regression model. Data intended to be subjected to hierarchical regression analysis were obtained from computed average scores on the two confirmed components of technology factors, two confirmed components of channel factors, one solid component of social factor and one resultant component of value for money factor, as identified earlier.

\begin{tabular}{|l|l|}
\hline Variable sets & Variables \\
\hline Demographic characteristics & Gender \\
& Age \\
& Level of Education \\
& Level of Income \\
& Ethnicity \\
& Occupation \\
\hline Technology factors & Perceived Usability \\
\hline & Perceived Trialability \\
\hline Channel factors & Perceived Safety \\
\hline & Perceived Specialty \\
\hline Social factors & Social factors \\
\hline Value for money factors & Value for money factors \\
\hline
\end{tabular}

Table 7 Variable sets and their constituent Predictors included in the Hierarchical Regression Analyses

The data pertaining to all the variables in Table VII were examined through the SPSS 17 program for data accuracy, normality and assumptions of multivariate analyses prior to the actual hierarchical regression analyses. Then list wise deletion method was considered to be the safest and most appropriate option from a statistical estimation perspective since there were minimal missing data.

\section{Explanation of the Model Predicting the Continued Use of Internet Banking}

Hierarchical multiple regression analysis was employed to test for the effects of all independent variable sets in predicting the continued use of internet banking as the dependent variable. Table VIII displays the different variable sets entered in their sequential order, the $R^{2}$ change and its associated degrees of freedom, the $F$ change (partial $F$-test) and associated $p$-value. The resultant regression 
weights obtained from the hierarchical multiple regression analysis is based on the log transformations of the independent variables. The right-hand portion of Table VIII lists the $p$-values for the individual independent variable sets contributing to the predictor variable at that step, relating to the variables analysed, the part (semi-partial) correlation, partial $\mathrm{F}$, and sig. $p$-value.

The Durbin-Watson statistic was used to test for the presence of serial correlation among the residuals that is the assumption of independence of errors, which requires that the residuals or errors in prediction do not follow a pattern from case to case (Meyers et al. 2006). The value of the DurbinWatson statistic ranges from 0 to 4 . As a general rule of thumb, the residuals are not correlated if the Durbin-Watson statistic is approximately two, and an acceptable range is 1.50-2.50 (Wilcox 1997). For the present research, the Durbin-Watson statistic of 2.10 falls within the acceptable range. The tolerance values for all the independent variables were larger than 0.10 , indicating that multicollinearity was not a problem in progressing with the proposed regression analysis (Cleveland 1984).

Table VIII displays a summary of the hierarchical multiple regression analysis with five models listed. At the end of each step model $\mathrm{R}^{2}$ was significantly different from zero. In the final model, with all the independent variable sets in the equation, the overall regression model was significant $\left(\mathrm{R}^{2}=0.42\right.$, adjusted $\left.\mathrm{R}^{2}=0.39, \mathrm{~F}=20.34, p<0.001\right)$. Thus, with all variable sets entered, nearly 43 percent of the variance in continued use of internet banking was explained.

In Model 1, the demographic characteristics set of variables did not contribute significantly to the prediction of continued use of internet banking $\left(\mathrm{R}^{2}\right.$ Change $=0.01, \mathrm{~F}$ Change $\left.=0.85, p=0.52\right)$. At Model 1, the demographic characteristics set were entered first in order to control for their influence. Demographic characteristics were examined to make sure that the effects attributed to later independent variable sets entered into the hierarchical multiple regression analysis were not due to demographic differences, thus removing their potential contaminating influence, if any. All other variable sets (i.e., technology, channel, social and value factors) were entered from Model 2 to Model 5 .

In Model 2, the technology factors contributed significantly to the prediction of continued use of internet banking over and above what the demographic characteristics set could predict $\left(\mathrm{R}^{2}\right.$ Change $=$ 0.23 , F Change $=55.87, p<0.001$ ). Thus, the technology factors set uniquely accounted for 23 percent of the variance in continued use of internet banking over and above the previously entered set. Among the technology factors set, the perceived usability component $\left(\mathrm{sr}^{2}=0.45\right.$, Partial $\mathrm{F}=10.04, p$ $<0.001)$ and perceived trialability component $\left(\mathrm{sr}^{2}=0.18\right.$, Partial $\left.\mathrm{F}=2.38, p<0.001\right)$ were significant in the explanation of the variance in continued use of internet banking at this step. Increases in perceived usability and perceived trialability were predictive of an increase in consumers' continued use of internet banking.

In Model 3, the channel factors contributed significantly to the explanation of variance in continued use of internet banking over and above what the demographic characteristics and technology factors set could predict $\left(\mathrm{R}^{2}\right.$ Change $=0.13, \mathrm{~F}$ Change $\left.=38.31, p<0.001\right)$. Thus, the channel factors set uniquely accounted for 14 percent of the variance of continued use of internet banking over and above the previously entered sets. Among the channel factors set, perceived safety $\left(\mathrm{sr}^{2}=0.23\right.$, Partial $\mathrm{F}=$ $5.69, p<0.001)$ and perceived specialty $\left(\mathrm{sr}^{2}=0.19\right.$, Partial $\left.\mathrm{F}=4.79, p<0.001\right)$ components were significant in the explanation of the variance in continued use of internet banking. Increases in perceived safety and perceived specialty were predictive of an increase in consumers' continued use 
of internet banking. Thus, respondents who strongly agreed on perceived safety and perceived specialty components of the channel factors were associated with a significant increase in their continued use of internet banking.

In Model 4, the social factors set did not add significantly to the prediction of continued use of internet banking $\left(\mathrm{R}^{2}\right.$ Change $=0.001, \mathrm{~F}$ Change $\left.=0.19, p<0.001\right)$. Thus, respondents did not consider social factors as significant predictors in determining their continued use of internet banking.

In Model 5, the value for money factors contributed significantly to the explanation of variance in continued use of internet banking over and above what the demographic characteristics, technology, channel and social factors could predict $\left(\mathrm{R}^{2}\right.$ Change $=0.05, \mathrm{~F}$ Change $\left.=35.49, p<0.001\right)$. Thus, the value for money factors set uniquely accounted for 6 percent of the variance of continued use of internet banking over and above the previously entered sets. Thus, respondents who strongly agreed on the value for money factors also tended to strongly agree on their significant increase in continued use of internet banking.

\begin{tabular}{|c|c|c|c|c|c|c|c|c|c|}
\hline Model & Variable Set & $\begin{array}{l}\mathrm{R}^{2} \\
\text { Change }\end{array}$ & $\mathrm{df}$ & $\begin{array}{l}\mathrm{F} \\
\text { Change }\end{array}$ & $\begin{array}{l}\text { Sig. F } \\
\text { Change }\end{array}$ & Variable & $\mathrm{sr}^{2}$ & $\begin{array}{l}\text { Partial } \\
\text { F }\end{array}$ & Sig. \\
\hline 1 & $\begin{array}{l}\text { Demographic } \\
\text { Characteristics }\end{array}$ & 0.01 & 6 & 0.85 & 0.52 & NS & & & \\
\hline \multirow[t]{2}{*}{2} & $\begin{array}{l}\text { Technology } \\
\text { Factors }\end{array}$ & 0.23 & 2 & 55.87 & $\begin{array}{l}< \\
0.001 *\end{array}$ & $\begin{array}{l}\text { Perceived } \\
\text { Usability }\end{array}$ & $\overline{0}-45$ & 10.04 & $\begin{array}{l}< \\
0.001 *\end{array}$ \\
\hline & & & & & & $\begin{array}{l}\text { Perceived } \\
\text { Trialability }\end{array}$ & 0.18 & 2.38 & $\begin{array}{l}< \\
0.001 *\end{array}$ \\
\hline 3 & Channel Factors & 0.13 & 2 & 38.31 & $\begin{array}{l}< \\
0.001 *\end{array}$ & $\begin{array}{l}\text { Perceived } \\
\text { Safety } \\
\text { Perceived } \\
\text { Specialty }\end{array}$ & $\begin{array}{l}0.23 \\
0.19\end{array}$ & $\begin{array}{l}5.69 \\
4.79\end{array}$ & $\begin{array}{l}\begin{array}{l}< \\
0.001 * \\
<\end{array} \\
0.001 *\end{array}$ \\
\hline 4 & Social Factors & 0.001 & 1 & 0.19 & 0.66 & NS & & & \\
\hline 5 & $\begin{array}{l}\text { Value for money } \\
\text { Factors }\end{array}$ & 0.05 & 1 & 35.49 & $\begin{array}{l}< \\
0.001 *\end{array}$ & $\begin{array}{l}\text { Value for } \\
\text { money } \\
\text { Factors }\end{array}$ & 0.23 & 35.49 & $\begin{array}{l}< \\
0.001 *\end{array}$ \\
\hline
\end{tabular}

Overall Model $\quad \mathrm{R}^{2}=0.42$, adjusted $\mathrm{R}^{2}=0.39, \mathrm{~F}=20.34,<0.001 *$

$* \leq 0.05$ considered significant

$0.05<p \leq 0.10$ considered marginally significant

Table 8: Hierarchical Multiple Regression Model Summary

Table IX provides the hypotheses testing outcomes of the hierarchical multiple regression analyses performed with continued use of internet banking as a dependent variable. 


\begin{tabular}{|c|c|}
\hline Hypothesis & Result \\
\hline $\begin{array}{l}\mathrm{H}_{1} \text { : Identified technology factors will significantly predict continued use of } \\
\text { internet banking over and above the influence of the demographic control } \\
\text { variables. } \\
\mathrm{H}_{1 \mathrm{~A}} \text { : Identified perceived usability component of the technology factors will } \\
\text { significantly predict continued use of internet banking over and above the } \\
\text { influence of the demographic control variables. } \\
\mathrm{H}_{1 \mathrm{~B}} \text { : Identified perceived trialability component of the technology factors will } \\
\text { significantly predict continued use of internet banking over and above the } \\
\text { influence of the demographic control variables. }\end{array}$ & $\begin{array}{l}\text { Supported } \\
\text { Supported } \\
\text { Supported }\end{array}$ \\
\hline $\begin{array}{l}\mathrm{H}_{2} \text { : Identified channel factors will significantly predict continued use of internet } \\
\text { banking over and above the influence of the demographic control variables and } \\
\text { technology factors. } \\
\mathrm{H}_{2 \mathrm{~A}} \text { : Identified perceived safety component of the channel factors will } \\
\text { significantly predict continued use of internet banking over and above the } \\
\text { influence of the demographic control variables and technology factors. } \\
\mathrm{H}_{2 \mathrm{~B}} \text { : Identified perceived specialty component of the channel factors will } \\
\text { significantly predict continued use of internet banking over and above the } \\
\text { influence of the demographic control variables and technology factors. }\end{array}$ & $\begin{array}{l}\text { Supported } \\
\text { Supported } \\
\text { Supported }\end{array}$ \\
\hline $\begin{array}{l}\mathrm{H}_{3} \text { : Identified social factors will significantly predict continued use of internet } \\
\text { banking over and above the influence of the demographic control variables, } \\
\text { technology and channel factors. }\end{array}$ & Not Supported \\
\hline $\begin{array}{l}\mathrm{H}_{4} \text { : Identified value for money factors will significantly predict continued use of } \\
\text { internet banking over and above the influence of the demographic control } \\
\text { variables, technology, channel and social factors. }\end{array}$ & Supported \\
\hline
\end{tabular}

Table 9: Hypotheses Testing Outcomes

\section{DISCUSSION}

The results obtained from the hierarchical multiple regression show the influence of value for money, channel and technology factors on consumers' continued use of internet banking. As the objective of the study was to identify variables of theoretical importance, demographic variables were controlled. As such demographic variables did not exert any influence on consumers' continued use of internet banking. Similarly, social factors did not exert any significant influence on consumers' continued use of internet banking as the comfort levels of the consumers' increases from their pre-adoption and adoption processes. It had been expected that the more the influence of the salient referent groups such as friends, colleagues and family to the consumer, the more would be the usage of internet banking by the consumer on a continued basis. It was assumed that general banking transactions may have been seen to be too private and confidential an activity for respondents to discuss in surveys. Therefore, consumers may not be interested in discussing their banking transactions with others within their social and family groups, thus reducing their potential influence on the usage of internet banking. Maybe the referent group influence could be contended to apply to pre-purchase and purchase stages of the consumer decision-making process, during which, due to the general apprehension associated with a service innovation, consumers tend to discuss the behaviour under 
question with salient referent groups. During the post-purchase stage, the influence of the referent groups might drastically reduce as consumers become more accustomed to the use of internet-based transactions. Further, as consumers use internet banking in the post-purchase stage more continuously and frequently, their familiarity with the service delivery channel and presence of the trialability option encourages them to use and try on their own, rather than involving social channels.

In the pre-specified hierarchical order of importance, value for money, channel and technology factors were identified to exert significant impact on consumers' continued use of internet banking. Thus, during the consumers' post-adoption process, consumers' perceptions of the value for money component play a pivotal role by taking into consideration the economic value of the internet banking service delivery channel, its cost effectiveness and its service quality. Moreover, consumers who experienced internet banking as safe, special, secure, convenient and easy tend to perform internet banking transactions on a continuous basis, thus indicating the importance of channel and technology factors.

It was expected that the more consumers perceive the value components associated with the use of internet banking service delivery channel, the more they use it on a continued basis. The results showed that consumers clearly weigh up the benefits and costs associated with various banking service delivery channels and tend to use the most profitable one. The above discussion was consistent with similar prior existing studies relating to the value perceptions of the consumers and their subsequent online store choice (Petrick 2002). Understanding value perceptions from the customer perspective is relevant for managing and supporting both the bank's and the customer's value creation processes. Further, understanding the dimensions of the value for money factors in this study complements previous theories on customer perceived value and helps in conceptualisation of the value specific to the electronic services. Financial entities should provide service offers that generate value to their customers in a sustained way, in order to attain a competitive advantage and maintain it over time. Thus, bank management, marketers and service providers should increasingly look at the possibilities of providing business customer value and enhance their profitability.

It had been expected that the emerged components 'perceived safety' and 'perceived specialty' of the channel factors would enhance consumers' usage of internet banking on a continued basis. The first component of research hypothesis two and its sub-components were supported, as perceived safety and perceived specialty exhibited a significant impact on consumers' continued usage of internet banking. These results showed that the more consumers perceive their internet banking service channel as safe to perform their banking transactions, the more they use it on a continued basis. A further finding was that the more consumers perceive that they were treated uniquely whilst making their online banking transactions, the more they tend to use internet banking on a continued basis. The perceived specialty aspects shed new light on the emerging research regarding consumers' usage of internet banking as existing research on this dimension is scarce.

It had also been expected that the emerged components 'perceived usability' and 'perceived trialability' of the technology factors would enhance consumers' usage of internet banking on a continued basis. Results from this study confirm the positive and significant relationship between perceived usability and perceived trialability components and consumers' continued use of internet banking. These results show that consumers often tend to evaluate various advantageous aspects of the different service delivery channels at the pre-purchase and purchase stages of their decision making process for internet banking products. The perceived usability and perceived trialability components of the technology-related factors still influence consumers' decisions long after the initial 
adoption of internet banking. As consumers become comfortable with the use of the technologyenabled service delivery channels in the post-purchase decision-making process, consumers become more oriented towards the usability nature of a specific channel and therefore continue to use it on a frequent basis. Perceived trialability could be related to the consumer's underlying fear of making mistakes in processing their financial transactions. Thus, consumers in an online environment tend to use the trialability feature to test whether transactions can be conducted safely and securely. Thus it is evident that highly experienced internet banking service delivery channel users still desire more useful alternatives.

Theoretically, this research helps to expand the current literature and understanding on the topic and provides a number of approaches for future research. This study relates to the understanding of consumers' post-adoption behaviour, unlike earlier studies that focused predominantly on consumers' pre-adoption behaviour. The contribution of this study is the investigation of integrated theory testing based on technology acceptance models and diffusion of innovations theory. This study investigates the conceptual model developed from integrated theory testing, to assess consumer's continued use of internet banking process by incorporating technology, channel, social and value for money factors. Technology, channel, social and value for money factors were conceptualised to measure consumers' continued use of internet banking to encompass diverse aspects of consumer behaviour, and not limiting its evaluation to consumer's acceptance and adoption of internet banking. Further, the distinct role of consumers' continued use of internet banking was investigated in the dynamics of technology, channel, social and value for money factors and strengthens the existing literature by examining the different impact of each component entered in the model. Furthermore, in order to limit the impact of confounding research findings and conclusions, the present findings showed the importance of controlling for the influence of demographic characteristics on criterion variables. The actual predictive power of the predictor variables would have resulted in erroneous estimations if demographic characteristics were not controlled for whilst undertaking hierarchical multiple regression analyses.

The outcomes from the present study add value to marketing research and practice in a broader perspective to the Australian financial sector and more specifically to the Australian retail banking industry in several ways. The relevance of the technology-related factors emphasises that the traditional focus of banking management on bank employee-customer interaction issues needs to be revised. Bank management essentially needs to reorient their focus on technology-customer interactions and effective management of the technology interface. Consumers' attitudes towards the internet banking service delivery channel would be different from those of traditional bank branches (Curran et al. 2003). Therefore, bank management may opt for the interconnectedness of all the service delivery channels as there is a potential possibility that positive attitudes of consumers towards an existing branch channel might create negative attitudes towards a proliferation of new electronic distribution channels. In order to enhance consumers' positive attitudes towards internet banking, banks may need to consider publicising widely the various advantages associated with the technology-related internet banking interface.

Banks could further consider highlighting the importance of the user-friendly features associated with internet banking in order to enhance consumers' perceptions towards the usability sub-dimension. The banks should also consider providing step-by-step instructions, opportunity to test-drive the technological interface, and possible demonstrations on how to use internet banking effectively and efficiently. Although a majority of the banks are proactive in providing step-by-step instructions to 
their modern customers about the use of electronic service delivery channels, possible demonstrations and feasible test-drive opportunities of the technological interfaces are available only with a few big banks. Banks may need to consider embarking on providing free training sessions to customers regarding the general use of computers and specific use of internet banking and educate them with the benefits associated with internet banking usage. Thus, bank marketers strive continuously to incorporate new and useful capabilities to improve the user-friendliness of their service offerings to the customers. Service providers of individual consumer-oriented applications should engage in constant efforts to positively influence consumers' perceptions as improved user satisfaction; broader usage and positive consumer perceptions are better defences against competitors.

As technology-enabled service delivery channels like internet banking constantly compete for user support, it is essential to understand what users take into consideration when choosing between available service delivery channel alternatives. Thus channel technology designers should always be vigilant of consumers, changing needs and never take consumer's satisfaction for granted. Thus bank management and marketers always strive to improve their products and services and further enhance consumers' satisfaction and loyalty, regardless of how successful they have been in the past. Banks are also developing strategies that will improve the consumer's trust in banking with the internet by development of secure policies and procedures, incorporation of secure mechanisms such as Secure Socket Layers (SSL), embracing encryption and firewall technologies, virus detection and protection measures, protective mechanisms including backup servers, and working coherently with online security firms which might reduce the perceptions of the consumers that the internet-based service delivery channels are uncertain and unsafe. Additionally, banks may need to focus on implementing effective mechanisms to address any violation of the consumer's sensitive data by placing adequate controls in place to ensure security of personal data.

Modern banks are also implementing cryptography techniques in order to protect the confidentiality of the consumer needs. During and after exchange of information between the consumer and the service provider, information content should be unchanged and tamper free through encryption and digital signatures. Information accessibility and availability should be delivered in as reliable and authorised a manner as possible. Banks are striving to provide appropriate measures to protect consumers' authentication and authorisation regarding their internet-based financial transactions through creation of passwords and access control policies. Banks may need to ensure non-repudiation measures such as confidentiality associated to information passed over the network during communication and stored at different locations through digital signatures and certificates issued to the internet banking users. Moreover, banks need to continue to protect consumers' privacy through various policies and disclosures.

Banks in future should demonstrate the ability to send personalised messages to their prospective and potential internet banking consumers eliciting them as unique customers and, when possible, retrieve consumers' feedback with regard to their service provision. Installation of voice prompts by bank management may create a sort of online personal help and thus attract more consumers to use internet banking channel. At this juncture, banks need to take advantage of marketing communications in reaching their effective target group in order to further enhance their productivity and maximise their profits. Brochures, seminars and online information content must be developed based on a clear understanding of the current knowledge level of the customers. Bank management may need to consider exerting a great effort whilst selecting and training the online contact personnel. Online 
contact personnel should also be monitored continuously over time regarding their appropriateness of their level of knowledge and their attitude towards customers.

Retail banking and marketing managers may need to have a coherent understanding of the relative importance of the various dimensions of value as perceived by customers during their evaluations and accordingly develop marketing strategies. Thus, bank management and retail banking marketers try to control or minimise the losses and strive to enhance customer loyalty through customer satisfaction by offering a comprehensive service. The relevant importance and hierarchical impact of the various predictor variables on consumers' continued use of internet banking would help bank marketers to effectively segment customers based on the motivations that drive their online banking behaviour, rather than on traditional methods.

\section{LIMITATIONS AND FUTURE DIRECTIONS}

One of the limitations associated with the current study is related to the reduced capacity to draw causal inferences that were inherent in the application of a survey type of research. The data for testing the conceptual model were obtained in a cross-sectional manner on a single occasion from a single source. Therefore the data collection method employed in this study had the potential for single source bias. Responses were obtained only from those respondents who agreed to answer the questionnaire by interception in a shopping mall. Therefore the findings invite speculation with regard to causal relations concerns and further testing would be essential for verification. In order to avoid any intervention of confounding and spurious relationships, demographic characteristics were statistically controlled for whilst performing hierarchical multiple regression analysis.

Another limitation of this study is the use of self-report measures associated with consumers' perceptions of internet banking. Such measures have the potential to confound findings due to common method variance. Although a limitation, nevertheless it was a convenient method that allowed the researcher to efficiently examine the large number of relevant variables from a wider sample. However, there was no sign of lack of discriminant validity, the usual sign of common method variance among the principal constructs. Also self-report measures have been successfully used in prior research (Yousafzai et al. 2005; Straub et al. 1995). The issue of generalisability is a limitation in most of the consumer behaviour studies and the present study is no exception. The study has been conducted in Australia and specifically targeted the retail banking consumers who were internet banking users and non-users. The resultant findings may vary with the application of the study to other banking contexts and other countries. Prior internet banking research indicated variation in the findings obtained when conducted in cross-cultural contexts (Unnithan \& Swatman 2001). This may possibly explain why some of the theorised relationships between certain factors and consumers' continued use of internet banking did not materialise. Therefore the present study could not either rule out or rule in the predicted effects in these areas unequivocally. This issue could be attributed partly to the complexities of the models tested.

Furthermore, this research did not investigate whether the predictor variables exhibit any differences as a function of consumers' familiarity, nature and type of internet banking transactions and would result in any moderating or mediating effects. Similarly, the study did not take into consideration Soderlund's intentions approach, commonly used in the consumers' repurchase intentions as the aforementioned focuses on customer satisfaction and customer familiarity variables. However, it is hoped that findings from this study will stimulate additional research and will enhance our 
understanding of the role of various factors exerted as predictor variables on consumers' continued use of internet banking outcomes.

Therefore, replication of similar research and samples would enhance our knowledge whether or not this absence of confirmation may be attributed to the industry-related sample. The findings obtained from the study relate to the financial services sector, retail banking industry in general and specifically address consumers' usage patterns of internet banking. Future research should focus on other related service sectors such as tourism; call centres and hospitality and consumers' perceptions related to their continued use of the relevant service provider's service. It is also imperative to study the influence of potential factors on consumers' perceptions and usage of products and services of credit unions, building societies and non-banking financial institutions and compare the findings with those of the retail banking industry to see if this would result in any similarities and differences. Future research could possibly encompass all the electronic service delivery channels in order to determine any variation in consumers' usage patterns. A further extension of the present research to the other nations and subsequent comparative analysis would result in interesting findings.

\section{REFERENCES}

Ajzen, I. \& Fishbein, M. 1980, Understanding Attitudes and Predicting Social Behaviour. PrenticeHall, Upper Saddle River, New Jersey.

Akinci, S., Akoy, S. \& Atilgan, E. 2004, Adoption of internet banking among sophisticated consumer segments in an advanced developing country. International Journal of Bank Marketing, 22 (3), 212-232.

Bagozzi, R. P. 2007, The legacy of the technology acceptance model and a proposal for a paradigm shift. Journal of the Association for Information Systems, 8 94), 243-254.

Bell, G. \& Lyman, M. M. 1999, Buying financial services: A model including the channel effect. Academy of Marketing Conference, Stirling.

Black, N. J., Lockett, A., Ennew, C., Winklhofer, H. \& McKechnie, S. 2002, Modelling consumer choice of distribution channels: An illustration from financial services. International Journal of Bank Marketing, 20 (4), 161-173.

Black, N. J., Lockett, A., Winjklhofer, H. \& Ennew, C. 2001, The adoption of internet financial services: A qualitative research. International Journal of Retail and Distribution Management, 29 (8), 390-398.

Bolton, R. N. \& Lemon, K. N. 1999, A dynamic model of customers' usage of services: Usage as an antecedent and consequence of satisfaction. Journal of Marketing Research, 36, 171-186.

Chan, S. \& Lu, M. 2004, Understanding internet banking adoption and use behaviour: A Hong Kong Perspective. Journal of Global Information Management, 12 (3), 21-43.

Chen, T. Y., Chang, P.L. \& Chang, H. S. 2005, Price, brand cues, and banking customer value. International Journal of Bank Marketing, 23 (3), 273-291.

Cleveland, W. S. 1984, Graphical methods for data presentation: Full scale breaks, dot charts, and multibased logging. The American Statistician, 38(4), 270-280. 
Cohen, J., Cohen, P., West, S. \& Aiken, L. 2003, Applied Multiple Regression/ Correlation Analysis for the Behavioural Sciences ( $3^{\text {rd }}$ ed.). Lawrence Erlbaum Associates, Mawah, New Jersey.

Cooksey, R. W. 1997, Statistics for Behavioural and Social Research: A Descriptive Handbook. University of New England, Armidale, Australia.

Cooksey, R. W. 2007, Illustrating statistical procedures: For business, behavioural \& social science research $\left(1^{\text {st }}\right.$ ed.). Tilde University Press, Australia.

Curran, J. M., Meuter, L. M. \& Suprenant, C. F. 2003, Intentions to use self service technologies: A confluence of multiple attitudes. Journal of Service Research, 5 (3), 209-224.

Daniel, E. 1999, Provision of electronic banking in the UK and the Republic of Ireland. International Journal of Bank Marketing, 17 (2), 72-82.

Desouza, K. C., Awazu, Y. \& Ramaprasad, A. 2007, Modifications and innovations to technology artefacts. Technovation, 27, 204-220.

Durkin, M. 2004, In search of the internet banking customer, exploring the use of decision styles. International Journal of Bank Marketing, 22(7), 484-523.

Durkin, M., Jennings, D., Mulholland, G. \& Worthington, S. 2008, Key influencers and inhibitors on adoption of the internet for banking. Journal of Retailing and Consumer Services, 15, 348-357.

Eriksson, K. \& Nilsson, D. 2007, Determinants of the continued use of self-service technology: The case of internet banking. Technovation, 27 (4), 159-167.

Falk, T., Schepers, J., Hammerschmidt, M. \& Grossenbacher, S. 2005, Should I stay or should I go The role of status quo for using new self-service technology. Retrieved $18^{\text {th }}$ May, 2008, from $\underline{\text { www.ssrn.com/abstract }=962242}$

Gefen, D., Karahanna, E. \& Straub, D. W. 2003, Trust and TAM in online shopping: An integrated model. MIS Quarterly, 27 (1), 51-90.

Gerrard, P. \& Cunningham, J. B. 2003, The diffusion of internet banking among Singapore consumers. International Journal of Bank Marketing, 21 (1), 16-28.

Graham, J. M. 2006, Congeneric and (essentially) equivalent estimates of score reliability: What they are and how to use them? Educational and Psychological Measurement, 66, 930-944.

Hair, J. F., Black, B., Babin, B., Anderson, R. E. \& Tatham, R. L. 2006, Multivariate Data analysis $\left(6^{\text {th }}\right.$ ed.). Prentice Hall, NJ.

Hammond, K. \& Ehrenberg, A. 1995, Heavy buyers: How many do you have? How important are they? Proceedings of the $24^{\text {th }}$ Annual Conference of the European Marketing Academy, 1651 1655.

Hernandez, J. M. C. \& Mazzon, J. A. 2007, Adoption of internet banking: Proposition and implementation of an integrated methodology approach. International Journal of Bank Marketing, 25 (2), 72-88.

Hernandez, O. D., Jimenez-Martinez, J. \& Jose Marti-De, H. M. 2008, B2C e-commerce acceptance: The moderating effect of gender. Communication of the IBIMA, 6 (16), 104-112. 
Jha, S., Papagari, S., Desouza, K. C., Seo, D. \& Ye, C. 2006, Technology failures and complaint management: Antecedents to post-adoption discontinuance of technology usage. Academy of Management Annual Meeting, Atlanta, Georgia.

Karmarkar, U. S. \& Pitbladdo, R. C. 1997, Quality, class, and competition. Management Science, 43 (1), 27-39.

Kasheir, D., Ashour, A. S. \& Yacout, O. M. 2009, Factors affecting continued usage of internet banking among Egyptian customers. Communication of the IBIMA, 9, ISSN: 1943-7765.

Keen, C., Wetzels, M., De Ruyter, K. \& Feinberg, R. 2004, E-tailers versus retailers: Which factors determine consumer preferences? Journal of Business Research, 57, 685-695.

Kerem, K., Lustsik, O., Sorg, M. \& Vensel, V. 2003, The development of e-banking in a EU candidate country: An Estonian case. Proceedings of International Atlantic Economic Society Conference, Vienna, March 11-17.

Kim, S. S. \& Malhotra, N. K. 2005, A longitudinal model of continued IS use: An integrative view of four mechanisms underlying post adoption phenomena. Management Science, 51 (5), 741-755.

Klopping, I. M. \& McKinney, E. 2004, Extending the technology acceptance model and the task technology fit model to consumer e-commerce. Information Technology, Learning, and Performance Journal, 22 (1), 35-48.

Lee, E., Lee, J. \& Eastwood, D. 2003, A two-step estimation of consumer adoption of technologybased service innovations. The Journal of Consumer Affairs, 37 (2), 256-282.

Lee, P. 1996, The cutting edge: So far, online banking is mostly wishful thinking. Los Angeles Times, September $30,1$.

Liao, S., Shao, Y. P., Wang, H. \& Chen, A. 1999, The adoption of virtual banking: An empirical study. International Journal of Information Management, 19, 63-74.

Liljander, V., Gillberg, F., Gunmerus, J. \& Riel, A. V. 2006, Technology readiness and the evaluation and adoption of self-service technologies. Journal of Retailing and Consumer Services, 13, 177-191.

Lindgreen, A. \& Wynstra, F. 2005, Value in business markets: What do we know? Industrial Marketing Management, 34, 732-748.

Lockett, A. \& Littler, D. 1997, The adoption of direct banking services. Journal of Marketing Management, 13, 791-811.

Lovelock, C. \& Wirtz, J. 2004, Services Marketing: People, Technology, Strategy (5 ${ }^{\text {th }}$ ed.). PrenticeHall, Upper Saddle River, NJ.

Lu, M. T., Liu, C. H., Jing, J. \& Huang, L. J. 2005, Internet banking: Strategic responses to the accession of WTO by Chinese banks. Industrial Management \& Data Systems, 105 (4), 429442 .

Ma, Q. \& Liu, L. 2004, The technology acceptance model: A meta-analysis of empirical findings. Journal of Organisational and end user Computing, 16 (1), 59-72. 
Mathieson, K. 1991, Predicting user intentions: Comparing the technology acceptance model with the theory of planned behaviour. Information Systems Research, 2 (3), 173-191.

McCole, P. \& Ramsey, E. 2009, A profile of adopters and non-adopters of ecommerce in SME professional service firms. Australasian Marketing Journal, 13, 36-45.

Mia, M. A. H., Rahman, M. A. \& Uddin, M. M. 2007, E-Banking evolution, status and prospects. The Cost and Management, 35 (1), 36-48.

Mick, D. G. \& Fournier, S. 1998, Paradoxes of technology: Consume cognizance, emotions, and coping strategies. Journal of Consumer Research, 25 (2), 123-143.

Moore, G. C. \& Benbasat, I. 1991, Development of an instrument to measure the perceptions of adopting an information technology. Information Systems Research, 2 (3), 173-191.

Morrison, P. D. \& Roberts, J. H. 1998, Matching electronic distribution channels to product characteristics: The role of congruence in consideration set formation. Journal of Business Research, 41 (3), 223-229.

Ndubisi, N. O. \& Sinti, Q. 2006, Consumer attitudes, system's characteristics and internet banking adoption in Malaysia. Management Research News, 29 (1/2), 16-27.

Oliver, R. L \& DeSarbo, W. S. 1988, Response determinants in satisfaction judgments. Journal of Consumer Research, 14, 495-508.

Parasuraman, A. 1997, Reflections on gaining competitive advantage through customer value. Journal of the Academy of Marketing Science, 25 (2), 154-161.

Parasuraman, A. 2000, Technology readiness index (TRI): A multiple-item scale to measure readiness to embrace new technologies. Journal of Service Research, 2 (4), 307-320.

Petrick, J. F. 2002, Development of a multi-dimensional scale for measuring the perceived value of service. Journal of Leisure Research, 34 (2), 119-134.

Reid, M. \& Levy, Y. 2008, Integrating trust and computer self-efficacy with technology acceptance model: An empirical assessment of customers' acceptance of banking information systems (BIS) in Jamaica. Journal of Internet Banking and Commerce, 12 (3). Retrieved $15^{\text {th }}$ April, 2009, from www.arraydev.com/commerce/jibc

Rhee, H. S. \& Riggins, F. 1999, GVU's WWW user surveys: High level summary of internet banking survey. Retrieved $10^{\text {th }}$ December, 2009, from www.gvu.gatech.edu/user-survey/survey-199704/graphs/banking/report.html

Rugimbana, R. 1995, Predicting automated teller machine usage: The relative importance of perceptual and demographic factors. International Journal of Bank Marketing, 13 (4), 26-32.

Rust, R. T. \& Espinoza, F. 2006, How technology advances influence business research and marketing strategy. Journal of Business Research, 59, 1072-1078.

Shih, Y. \& Fang, K. 2004, The use of decomposed theory of planned behaviour to study internet banking in Taiwan. Internet Research, 14 (3), 213-223.

SPSS. 2008, SPSS 17.0.1 for Windows. SPSS Inc., Chicago, Illinois. 
Srinivasan, S. S., Anderson, R. \& Ponnavolu, K. 2002, Customer loyalty in e-commerce: An exploration of its antecedents and consequences. Journal of Retailing, 78 (1), 41-50.

Straub, D., Limayem, M. \& Karahanna-Evaristo, E. 1995, Measuring system usage: Implications for IS theory testing. Management Science, 41, 1328-1342.

Sweeney, J. C. \& Soutar, G. 2001, Consumer perceived value: The development of multiple item scale. Journal of Retailing, 77 (2), 203-220.

Tan, M. \& Teo, T. S. H. 2000, Factors influencing the adoption of internet banking. Journal of the Association for Information Systems, 1, 1-42.

Taylor, S. \& Todd, P. A. 1995, Understanding information technology usage: A test of competing models. Information Systems Research, 6 (2), 144-176.

Thomas, J. \& Sullivan, U. 2005, Managing marketing communications with multichannel customers. Journal of Marketing (October), 239-251.

Thornton, T. \& White, L. 2001, Customer orientations and usage of financial distribution channels. Journal of Services Marketing, 15 (3), 168-184.

Tzokas, N. \& Saren, M. 1999, Value transformation in relationship marketing. Australasian Marketing Journal, 7, 52-62.

Unnithan, C. R. \& Swatman, P. M. C. 2001, eBanking adaptation and dot.com viability - A comparison of Australian and Indian experiences in the banking sector. Proceedings of the $11^{\text {th }}$ BIT 2001 Conference, Manchester, UK.

Venkatesh, V. \& Davis, F. D. 2000, A theoretical extension of the technology acceptance model: Four longitudinal studies. Management Science, 46 (2), 186-204.

Venkatesh, V., Morris, M. G., Davis, G. B. \& Davis, F. D. 2003, User acceptance of information technology: Toward a unified view. MIS Quarterly, 27 (3), 425-478.

Walker, R. H. \& Johnson, C. W. 2006, Why consumers use and do not use technology-enabled services. The Journal of Services Marketing, 20 (2), 125-135.

Walker, R. H., Craig-Lees, M., Hecker, R. \& Francis, H. 2002, Technology-enabled service delivery: An investigation of reasons affecting customer adoption and rejection. International Journal of Service Industry Management, 13 (1), 91-106.

Wilcox, R. R. 1997, Some practical reasons for reconsidering the Kolmorogov-Smirnov test. British Journal of Mathematical and Statistical Psychology, 50(1), 9-20.

Wresch, W. \& Fraser, S. 2006, Managerial strategies used to overcome technological hurdles: A review of e-commerce efforts used by innovative Carribean managers. Journal of Global Information Management, 14 (3), 1-16.

Yang, Z. \& Peterson, R. T. 2004, Customer perceived value, satisfaction, and loyalty: The role of switching costs. Psychology and Marketing, 21 (10), 799-822.

Ye, C., Seo, D. B., Desouza, K. C., Sangareddy, S. P. \& Jha, S. 2008, Influence of information technology substitutes and user experience on post-adoption user switching: An empirical 
investigation. Journal of the American Society for Information Science and Technology, 59 (13), 2116-2132.

Yousafzai, S. Y., Pallister, J. G. \& Foxall, G. R. 2003, A proposed model of e-trust for electronic banking. Technovation, 23, 847-860.

Yousafzai, S. Y., Pallister, J. G. \& Foxall, G. R. 2005, Strategies for building and communicating trust in electronic banking: A field experiment. Psychology and Marketing, 22 (2), 181-201.

Yu, J., Ha, I., Choi, M. \& Rho, J. 2005, Extending the TAM for a t-commerce. Information and Management, 42 (7), 965-976.

Zeithaml, V. A. 1988, Consumer perceptions of price, quality, and value: A means-end model and synthesis of evidence. Journal of Marketing, 52 (7), 2-22.

Zeithaml, V. A., Parasuraman, A. \& Malhotra, A. 2002, Service quality delivery through web sites: A critical review of extant knowledge. Journal of Academy of Marketing Science, 30 (4), 362375. 